\title{
FUTURE CHANGES IN EXTREME TEMPERATURE INDICES IN CLUJ-NAPOCA, ROMANIA
}

\author{
A.F. CIUPERTEA, A. PITICAR, V. DJURDJEVIC, \\ Adina-Eliza CROITORU, Blanka BARTOK
}

\begin{abstract}
Future changes in extreme temperature indices in ClujNapoca, Romania. At present, research in climatology is mainly focusing on climate change and especially on global warming. Since climate change is already affecting large areas worldwide, it is important to study in details these changes at regional and local scale and to reduce its negative impact. The aim of this study is to analyze changes on extreme temperature indices over the periods 2041-2070 and 2071-2100 in Cluj-Napoca city using a set of 21 indices recommended by Expert Team for Climate Change Detection Monitoring and Indices. Extreme temperature indices for observed and modeled data were calculated by employing ClimPACT2 software. Modeled data for daily minimum and maximum temperature was extracted from EURO-CORDEX Project database. RCP4.5 and RCP8.5 scenarios of three regional climate models (RACMO22E, RCA4, and WRF331F) were considered. Next we compared the average values of the historical period (1981-2010) with the 2041-2070 and 2071-2100 periods for each scenario (RCP 4.5 and RCP 8.5) in order to obtain the future changes. The result of this study shows major changes for all the analyzed indices. The period 20712100 presents the highest changes under both analyzed scenarios.
\end{abstract}

Keywords: climate change, extreme temperature indices, bias correction, regional climate models, Cluj-Napoca.

\section{INTRODUCTION}

At present, research in climatology is focusing on climate change and especially on global warming. Since climate change is already affecting large areas worldwide, it is important to study in details these changes at regional and local scale in order to reduce its negative impact.

Extreme temperatures are expected to be one of the most affected climatic parameters (Alexander et al., 2006; Kržič et al., 2011; Croitoru and Piticar, 2013). Many studies on historical data indicated significant changes of extreme temperatures (Spinoni et al., 2015; Croitoru and Piticar, 2013). Analysis of climate models projections under different scenarios showed that changes will continue in the future even at higher rates. However, scientific assessments on future climate changes in Romania are very limited (Scripcă et al., 2016; Cheval et al., 2017).

The aim of this study is to analyze changes on extreme temperature indices over the period 2041-2100 in Cluj-Napoca, using a set of 21 indices recommended by Expert Team for Climate Change Detection Monitoring and Indices (ETCCDMI). These indices have been already used in many previous studies from 
different regions of the world (Alexander et al., 2006; Kioutsioukis et al., 2010; Kržič et al., 2011; Croitoru and Piticar, 2013).

\section{DATA AND METHODS}

\subsection{Study Area}

Cluj-Napoca is the second most populated city in Romania after Bucharest, the capital, and the largest and most populated urban center in central and northwestern part of Romania. It is located at the contact of Apuseni Mountains and Transylvanian Plateau, in the valley of the Someșul Mic River. The climate of Cluj-Napoca City is temperate continental with weak oceanic influences.

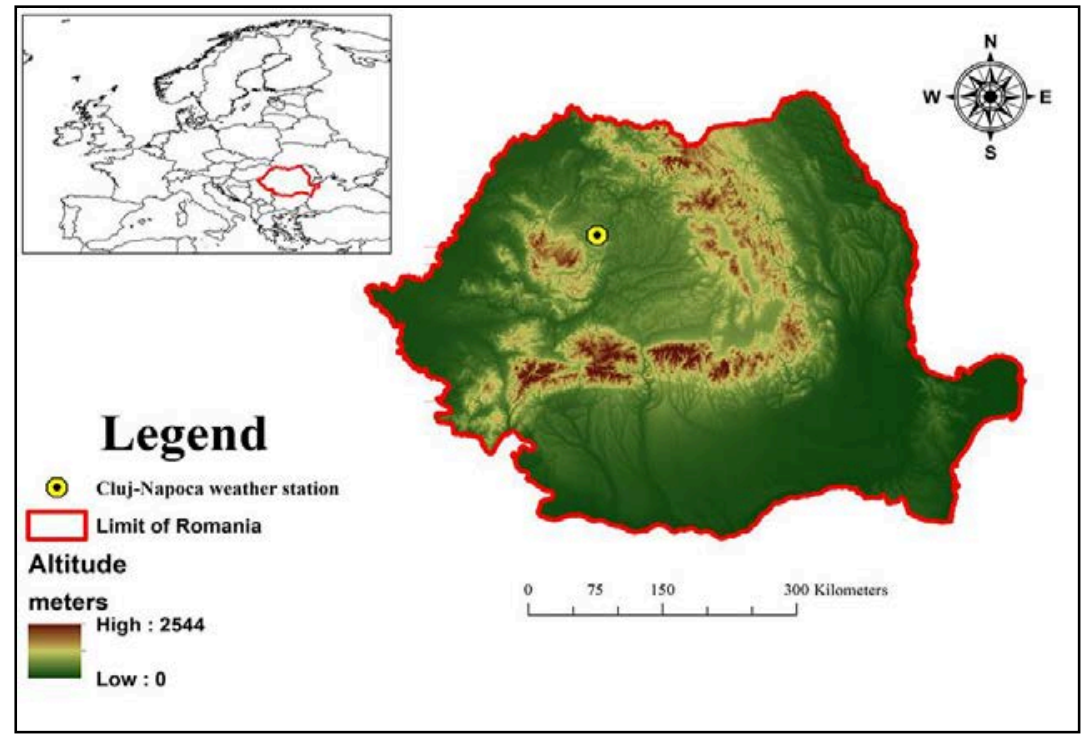

Fig. 1. Location of Cluj-Napoca weather station

\subsection{Data}

To identify changes in extreme temperature indices the observed (19812010) and modeled (2041-2100) daily maximum and minimum temperature data series of Cluj-Napoca weather station (Fig. 1) has been used. Cluj-Napoca weather station (WMO ID: 15120) is located in northwestern Romania (geographical coordinates 46 $46^{\prime} 39^{\prime}$ ' $\mathrm{N}$ and $23^{\circ} 34^{\prime} 17^{\prime \prime}$ E, 410 m altitude).

The historical datasets, were obtained from the European Climate Assessment and Database project database (non-blend data) (Klein Tank et al., 2002), from www.rp5.ru and by retrieving from synoptic messages available on www.meteomanz.com. The observed datasets were checked for quality control (QC) by the FMETPRO project team (http://fmetpro.granturi.ubbcluj.ro) employing the ClimPACT2 software developed by Alexander and Herold (2016). For modeled data series we analyzed the outputs from EURO-CORDEX project (Jacob et al., 2014), available at https://esgf-data.dkrz.de. The EURO-CORDEX 
Project provides an interface of climate simulations to the applicants for climate change impact, adaptation, and mitigation studies. For this study, the simulations were conducted for the spatial resolution 0.1 degree $(\sim 12.5 \mathrm{~km})$. Three regional climate models (RCMs) have been selected for this study under RCP 4.5 and RCP 8.5 scenarios: RACMO22E, RCA4, and WRF331F.

\subsection{Methods}

\subsubsection{Bias correction}

RCM outputs are generally biased and it is necessary to correct them. Therefore, to reduce systematic model errors in the climate variables we used quantile mapping method. It is a method applied to correct biases of regional climate model simulations compared to observational data (Themeßl et al., 2012; Maraun D., 2013). After biases correction we assessed which model overestimate or underestimate temperature values by comparing the observed data with the modeled data in the historical period.

\subsubsection{Extreme Indices calculation}

A set of 21 extreme temperature indices, recommended by ETCCDMI, were calculated with ClimPACT2 (Alexander and Herold, 2016) for both observed and modeled data. A detailed list and their calculation procedure is presented in Table 1.

Table 1. List of the ETCCDMI Climate Indices

\begin{tabular}{|c|c|c|c|}
\hline ID & INDEX NAME & DEFINITION & UNITS \\
\hline \multicolumn{4}{|c|}{ Hot Extreme } \\
\hline SU25 & "Summer days & Annual count when TX (daily maximum) $>25^{\circ} \mathrm{C}$ & Days \\
\hline TR20 & Tropical nights & Annual count when TN (daily minimum) $>20^{\circ} \mathrm{C}$ & Days \\
\hline SU30 & Tropical days & Annual count when TX (daily maximum) $>30^{\circ} \mathrm{C}$ & Days \\
\hline SU35 & Very hot days & Annual count when TX (daily maximum) $>=35^{\circ} \mathrm{C}$ & Days \\
\hline TN90p & Warm nights & Percentage of days when TN $>$ 90th percentile & Days \\
\hline TX90p & Warm days & Percentage of days when TX $>$ 90th percentile & Days \\
\hline $\mathrm{TXx}$ & Max Tmax & $\begin{array}{l}\text { Annual maximum value of daily maximum } \\
\text { temperature }\end{array}$ & ${ }^{\circ} \mathrm{C}$ \\
\hline $\mathrm{TXn}$ & Min Tmax & $\begin{array}{l}\text { Annual minimum value of daily maximum } \\
\text { temperature }\end{array}$ & ${ }^{\circ} \mathrm{C}$ \\
\hline TXmean & Mean Tmax & Annual mean value of daily maximum temperature & ${ }^{\circ} \mathrm{C}$ \\
\hline WSDI & $\begin{array}{l}\text { Warm spell duration } \\
\text { indicator }\end{array}$ & $\begin{array}{l}\text { Annual number of days contributing to events where } \\
6 \text { or more consecutive days experience TX }>90 \text { th }\end{array}$ & Days \\
\hline \multicolumn{4}{|c|}{ Cold Extreme } \\
\hline FD0 & Frost days & Annual count when TN (daily minimum) $<0{ }^{\circ} \mathrm{C}$ & Days \\
\hline ID0 & Ice days & Annual count when TX (daily maximum) $<0{ }^{\circ} \mathrm{C}$ & Days \\
\hline FN-10 & Frost nights & Annual count when TN (daily minimum) $<-10^{\circ} \mathrm{C}$ & Days \\
\hline TN10p & Cool nights & Percentage of days when $\mathrm{TN}<10$ th percentile & Days \\
\hline TX10p & Cool days & Percentage of days when TX $<10$ th percentile & Days \\
\hline $\mathrm{TNx}$ & Max Tmin & $\begin{array}{l}\text { Annual maximum value of daily minimum } \\
\text { temperature }\end{array}$ & ${ }^{\circ} \mathrm{C}$ \\
\hline TNn & Min Tmin & $\begin{array}{l}\text { Annual minimum value of daily minimum } \\
\text { temperature }\end{array}$ & ${ }^{\circ} \mathrm{C}$ \\
\hline
\end{tabular}




\begin{tabular}{|l|l|l|l|}
\hline TNmean & Mean Tmin & Annual mean value of daily minimum temperature & ${ }^{\circ} \mathrm{C}$ \\
\hline CSDI & $\begin{array}{l}\text { Cold spell duration } \\
\text { indicator }\end{array}$ & $\begin{array}{l}\text { Annual number of days contributing to events where } \\
6 \text { or more consecutive days experience TN }<10 \text { th } \\
\text { percentile }\end{array}$ & Days \\
\hline Variability extremes & $\begin{array}{l}\text { Diurnal temperature } \\
\text { range }\end{array}$ & Mean difference between daily TX and daily TN & ${ }^{\circ} \mathrm{C}$ \\
\hline DTR season & $\begin{array}{l}\text { Growing } \\
\text { Length }\end{array}$ & $\begin{array}{l}\text { Annual count between first span of at least } 6 \text { days } \\
\text { with }>5^{\circ} \mathrm{C} \text { and the first occurrence after } 1 \text { st July of at } \\
\text { least } 6 \text { consecutive days with TG }<5^{\circ} \mathrm{C}\end{array}$ & Days \\
\hline
\end{tabular}

*TX - daily maximum temperature; TN - daily minimum temperature

\subsubsection{Changes in extreme indices}

To identify future changes, we calculated the indices presented in Table 1 for the historical period 1981-2010 and for the period 2041-2100. The period 20412100 was divided into two sub-periods (2041-2070; 2071-2100). Then, we compared the values of the historical period with these two sub-periods for each scenario (RCP 4.5 and RCP 8.5).

\section{RESULTS AND DISCUSSIONS}

\subsection{Comparison between historical observed and modeled data}

To analyze the performance of the bias correction applied by quantile mapping method, we compared observed data with uncorrected modeled data and also observed data with corrected modeled data for 1981-2010 period (Fig. 2).
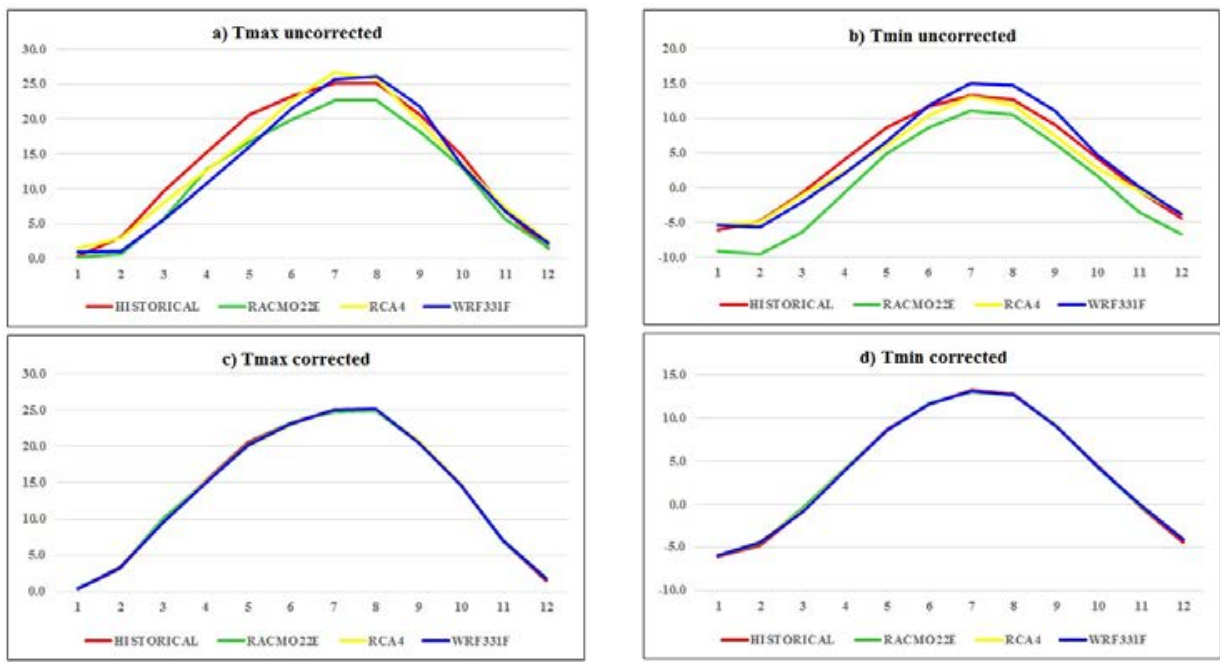

Fig. 2. Average monthly values of observed and modeled data for 1981-2010 period 
Comparison between the historical observed and uncorrected modeled data (Fig. 2a, b) showed that, in general, the three models underestimate both TX and TN. Differences between average values of observed and modeled data were between $0.0-4.6{ }^{\circ} \mathrm{C}$ for $\mathrm{TX}$ and $0.0-5.7^{\circ} \mathrm{C}$ for TN. After applying the bias correction, historical vs modeled data indicated almost identical values (Fig. 2c,d). The differences between observed and modeled data were found in the range 0.0 $0.5^{\circ} \mathrm{C}$ for TX and $0.0-0.4^{\circ} \mathrm{C}$ for TN.

\subsection{Changes under RCP 4.5 scenario}

For the RCP 4.5 scenario, the average values of extreme temperature indices over the period 2041-2100 will be higher than the values recorded in the historical period, especially for hot indices, indicating a warming at Cluj-Napoca (Table 2).

Table 2. Values of extreme indices in the historical period and for the future under RCP 4.5 scenario

\begin{tabular}{|c|c|c|c|c|c|c|c|c|c|}
\hline \multirow{2}{*}{ Indices } & \multirow{2}{*}{$1981-2010$} & \multicolumn{7}{|c|}{ RCP 4.5 scenario } \\
\cline { 2 - 11 } & & \multicolumn{3}{|c|}{$2041-2070$} & \multicolumn{3}{|c|}{$2071-2100$} \\
\cline { 2 - 11 } & Historical & RACMO22E & RCA4 & WRF331F & Average* & RACMO22E & RCA4 & WRF331F & Average* \\
\hline SU25 & 60.4 & 66.5 & 79.2 & 86.7 & 77.5 & 72.6 & 87.4 & 86.6 & 82.2 \\
\hline TR20 & 0.2 & 1.9 & 4.1 & 1.8 & 2.6 & 2.9 & 5.7 & 2.9 & 3.8 \\
\hline SU30 & 11.7 & 17.5 & 26.7 & 30.9 & 25.1 & 18.1 & 33.9 & 34.6 & 28.9 \\
\hline SU35 & 0.3 & 1.6 & 2.9 & 4.8 & 3.1 & 1.7 & 4.1 & 4.8 & 3.5 \\
\hline TN90p & 10.4 & 20.4 & 22.6 & 21.6 & 21.6 & 28.3 & 27.1 & 27.2 & 27.5 \\
\hline TX90p & 10.6 & 15.7 & 21.0 & 21.3 & 19.3 & 20.0 & 26.8 & 24.8 & 23.9 \\
\hline TXx & 33.4 & 34.8 & 35.7 & 35.8 & 35.4 & 35.4 & 36.3 & 36.2 & 36.0 \\
\hline TXn & -9.3 & -7.7 & -5.2 & -6.3 & -6.4 & -7.0 & -3.1 & -4.3 & -4.8 \\
\hline TXmean & 14.3 & 15.2 & 16.1 & 16.1 & 15.8 & 16.2 & 16.9 & 16.6 & 16.6 \\
\hline WSDI & 5.0 & 17.7 & 27.9 & 32.7 & 26.1 & 32.0 & 39.9 & 42.5 & 38.1 \\
\hline FD0 & 116.8 & 92.0 & 88.9 & 88.7 & 89.9 & 73.1 & 82.3 & 80.1 & 78.5 \\
\hline ID0 & 35.5 & 28.5 & 17.7 & 19.4 & 21.8 & 16.7 & 9.5 & 12.5 & 12.9 \\
\hline FN-10 & 17.9 & 14.8 & 5.6 & 5.5 & 8.6 & 6.4 & 1.5 & 3.0 & 3.6 \\
\hline TN10p & 10.5 & 4.7 & 2.2 & 3.9 & 3.6 & 2.0 & 1.2 & 2.7 & 2.0 \\
\hline TX10p & 10.6 & 7.7 & 4.3 & 5.7 & 5.9 & 4.7 & 3.2 & 5.0 & 4.3 \\
\hline TNx & 18.7 & 20.1 & 21.3 & 20.5 & 20.6 & 20.7 & 22.1 & 21.1 & 21.3 \\
\hline TNn & -18.3 & -15.8 & -12.3 & -13.0 & -13.7 & -13.7 & -9.1 & -10.6 & -11.1 \\
\hline TNmean & 4.2 & 5.6 & 6.2 & 6.0 & 5.9 & 6.7 & 6.9 & 6.6 & 6.7 \\
\hline CSDI & 3.9 & 4.0 & 1.1 & 1.5 & 2.2 & 1.2 & 0.4 & 1.1 & 0.9 \\
\hline DTR & 10.0 & 9.6 & 9.9 & 10.1 & 9.9 & 9.5 & 10.0 & 10.0 & 9.8 \\
\hline GSL & 234.5 & 256.5 & 261.8 & 260.4 & 259.5 & 271.0 & 273.1 & 268.7 & 270.9 \\
\hline
\end{tabular}

*Average of the three models for each sub-period

This increase is more consistent over the period 2071-2100. Most of the cold extreme indices (FD0, ID0, FN-10, TN10p, TX10p) indicate lower values for both future periods and for all models considered. Lower values of these indices also suggest a warming for the future periods. 


\subsection{Changes under RCP 8.5 scenario}

As expected, the RCP 8.5 shows that over the period 2041-2100 the values of extreme temperature indices will be even higher compared to those of RCP 4.5 scenario (Table 3). Increasing and decreasing values for different indices for the future periods are consistent with RCP 4.5 scenario.

Table 3. Values of extreme indices in the historical period and for the future under RCP 8.5 scenario

\begin{tabular}{|c|c|c|c|c|c|c|c|c|c|}
\hline \multirow{2}{*}{ Indices } & \multirow{2}{*}{$1981-2010$} & \multicolumn{9}{|c|}{ RCP 8.5 scenario } \\
\cline { 2 - 11 } & & \multicolumn{3}{|c|}{$2041-2070$} & \multicolumn{4}{|c|}{ 2071-2100 } \\
\cline { 2 - 11 } & Historical & RACMO22E & RCA4 & WRF331F & Average* & RACMO22E & RCA4 & WRF331F & Average* \\
\hline SU25 & 60.4 & 67.5 & 92.1 & 88.6 & 82.7 & 99.8 & 116.4 & 105.7 & 107.3 \\
\hline TR20 & 0.2 & 3.1 & 8.4 & 5.6 & 5.7 & 12.7 & 28.3 & 23.8 & 21.6 \\
\hline SU30 & 11.7 & 17.8 & 36.3 & 39.0 & 31.0 & 34.8 & 59.3 & 57.8 & 50.7 \\
\hline SU35 & 0.3 & 0.9 & 5.4 & 5.9 & 4.1 & 5.2 & 17.2 & 16.0 & 12.8 \\
\hline TN90p & 10.4 & 26.2 & 30.3 & 28.5 & 28.3 & 51.0 & 50.1 & 44.7 & 48.6 \\
\hline TX90p & 10.6 & 17.9 & 28.5 & 24.4 & 23.6 & 33.6 & 41.5 & 38.1 & 37.7 \\
\hline TXx & 33.4 & 34.4 & 37.1 & 36.4 & 36.0 & 37.1 & 39.2 & 39.1 & 38.5 \\
\hline TXn & -9.3 & -7.7 & -4.0 & -5.9 & -5.9 & -4.1 & -1.8 & -3.1 & -3.0 \\
\hline TXmean & 14.3 & 15.7 & 17.1 & 16.4 & 16.4 & 18.1 & 19.0 & 18.3 & 18.5 \\
\hline WSDI & 5.0 & 20.3 & 41.5 & 38.4 & 33.4 & 63.6 & 71.9 & 68.3 & 67.9 \\
\hline FD0 & 116.8 & 75.9 & 76.0 & 81.7 & 77.9 & 44.6 & 51.1 & 55.7 & 50.5 \\
\hline ID0 & 35.5 & 21.5 & 10.6 & 16.0 & 16.0 & 8.6 & 3.9 & 6.6 & 6.4 \\
\hline FN-10 & 17.9 & 9.7 & 3.0 & 5.2 & 6.0 & 3.0 & 0.3 & 0.9 & 1.4 \\
\hline TN10p & 10.5 & 2.8 & 1.1 & 3.1 & 2.3 & 0.6 & 0.2 & 0.6 & 0.4 \\
\hline TX10p & 10.6 & 6.4 & 3.0 & 5.7 & 5.0 & 2.1 & 1.1 & 2.3 & 1.8 \\
\hline TNx & 18.7 & 20.5 & 22.6 & 21.5 & 21.5 & 22.9 & 25.2 & 23.7 & 23.9 \\
\hline TNn & -18.3 & -15.1 & -9.6 & -12.0 & -12.2 & -11.7 & -6.6 & -8.8 & -9.1 \\
\hline TNmean & 4.2 & 6.4 & 7.2 & 6.5 & 6.7 & 8.7 & 9.2 & 8.3 & 8.7 \\
\hline CSDI & 3.9 & 1.9 & 0.2 & 0.7 & 0.9 & 0.0 & 0.0 & 0.3 & 0.1 \\
\hline DTR & 10.0 & 9.3 & 9.9 & 9.9 & 9.7 & 9.4 & 9.8 & 10.0 & 9.7 \\
\hline GSL & 234.5 & 273.4 & 271.5 & 264.1 & 269.7 & 298.3 & 289.2 & 292.0 & 293.2 \\
\hline
\end{tabular}

*Average of the three models for each sub-period

The results for the period 2071-2100 shows the most alarming values of extreme temperature indices. Thus, SU25 shows an increase of 30 days more than the historical average values, representing an increase of 178\%; SU30 recorded an increase of 20 days more than the historical average values (433\%); $T X x$ recorded an increase of $4{ }^{\circ} \mathrm{C}$ degrees more than the historical average values; TN mean recorded an increase of almost $4{ }^{\circ} \mathrm{C}$ more than the historical average values; GSL recorded an increase of 35 days for 2041-2070 period, and 59 for 2071-2100 period more than the historical average values. The results for RCP 8.5 scenario showed that TNn and TNmean will increase more than TXx and TXmean indices suggesting that minimum temperature will increase faster than maximum temperature. This is also the case of RCP 4.5 scenario. One of the most spectacular change has been found in a heat wave related index (WSDI), which indicates, on average, 5 days for 
historical observed data, while for the future 33 days for the interval 2041-2070 and 68 days for the sub-period 2071-2100.

\section{CONCLUSIONS}

In this study changes in extreme temperature indices have been analyzed for 2041-2070 and 2071-2100 periods using historical observed data (1981-2010) and modeled data from three RCMs (RACMO22E, RCA4, WRF331F) under RCPs 4.5 and 8.5 scenarios in Cluj-Napoca. After applying bias corrections on RCMs output data, systematic model errors have been significantly reduced. The results show important changes for both future sub-periods compared to the historical one. The period 2071-2100 shows the highest changes in the average values of extreme temperature indices compared to the historical and 2041-2070 periods for both analyzed scenarios. Since present changes in extreme temperature indices will continue in the future at higher rates, this study could be useful as a tool for developing adaptation strategies for Cluj-Napoca.

Acknowledgements. This research was developed under the framework of the research grant Extreme weather events related to air temperature and precipitation in Romania (project code: PN-II-RU-TE-2014-4-0736), funded by the Executive Unit for Financing Higher Education, Research, Development, and Innovation (UEFISCDI) in Romania.

\section{REFERENCES}

1. Alexander, Lisa et al., (2006), Global observed changes in daily climate extremes of temperature and precipitation. Journal of Geophysical Research 111, DOI:10.1029/2005JD006290.

2. Alexander, Lisa, Herold, N., (2016). ClimPACT2 Indices and software, The University of South Wales, Sidney, Australia. https://github.com/ARCCSSextremes/climpact2.

3. Cheval, S., Dumitrescu, A., Birsan, M.V., (2017), Variability of the aridity in the South-Eastern Europe over 1961-2050. Catena, 151, 74-86.

4. Croitoru, Adina-Eliza, Piticar, A., (2013). Changes in daily extreme temperatures in the extra-Carpathians regions of Romania. International Journal of Climatology, 33, 1987-2001, DOI: 10.1002/joc.3567.

5. Daniela, Jacob, et al., (2014), EURO-CORDEX: new high-resolution climate change projections for European impact research. Regional Enviromental Change 14, 563-578.

6. Kioutsioukis, I., Melas, D., Zerefos, C., (2010), Statistical assessment of changes in climate extremes over Greece (1955-2002). International Journal of Climatology 30, 1723-1737, DOI: 10.1002/joc.2030.

7. Klein Tank, A.M.G., Wijngaard, J.B., Konnen, G.P. et al., (2002), Daily dataset of 20th century surface air temperature and precipitation series for the European climate assessment. International Journal of Climatology 22, 1441-1453. 
8. Kržič, A., Tošić, I., Djurdjević, V., Veljović, K., Rajković, B., (2011), Changes in climate indices for Serbia according to the SRES-A1B and -A2. Climate Research, DOI: $10.3354 / \mathrm{cr} 01008$.

9. Maraun, D., (2013), Bias Correction, Quantile Mapping, and Downscaling: Revisiting the Inflation Issue. Journal of Climate 26, 2137-2143, DOI: 10.1175/JCLI-D-12-00821.1.

10. Scripcă, Andreea-Sabina, Strapazan, Carina, Holobâcă, I.-H., (2016), Regional Aspects of the variability of atmospheric precipitation in winter and summer seasons in Europe during 2001-2090. Air and water: Components of the Environment. Conference Proceedings, 143-151, DOI: 10.17378/AWC2016_18

11. Spinoni, J., Lakatos, M., Szentimrey, T., Bihari, Z., Szalai, S., Vogt, J., Antofie, T., 2015. Heat and cold waves trends in Carpathian Region from 1961 to 2010. International Journal of Climatology 35, 4197-4209. DOI: 10.1002/joc.4279.

12. Themeßl, M.J., Gobiet, A., Heinrich, G., (2012), Empirical-statistical downscaling and error correction of regional climate models and its impact on the climate change signal. Climatic Change 112, 449-468. 